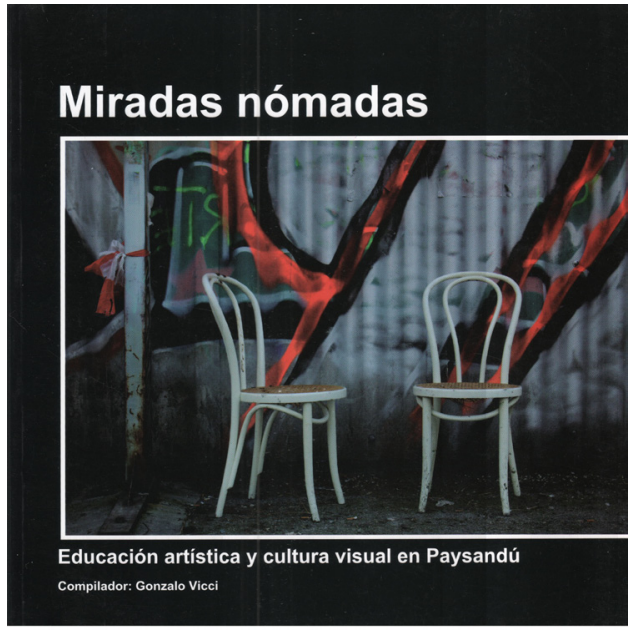

Miradas nómadas. Educación artística y cultura visual en Paysandú

Compilador: Gonzalo Vicci

Año: 2013. Lugar: Paysandú (Uruguay)

Editorial: Instituto Escuela Nacional de Bellas Artes. Universidad de la República. Páginas: 94

ISBN: 978-9974-0-0959-2

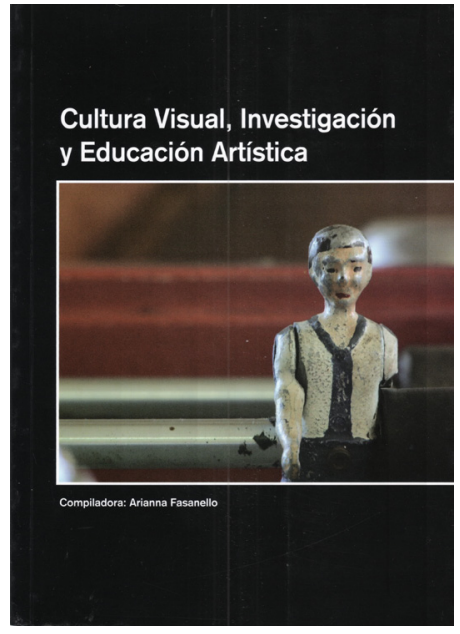

Cultura visual, investigación $y$ educación artística

Compiladora: Arianna Fasanello, Arianna

Año: 2014. Lugar: Montevideo (Uruguay)

Editorial: Instituto Escuela Nacional de Bellas Artes. Universidad de la República. Páginas: 168

ISBN: 978-9974-0-1059-8

\title{
El espacio de la educación artística necesita pensarse a sí mismo de manera permanente
}

Tomo como título una frase de Gonzalo Vicci que me resulta atractiva y que define el motivo de esta reseña bicéfala, ya que parte de la revisión de dos títulos que nos llegan desde Uruguay. Por suerte he podido seguir de cerca y desde hace años el interesante trabajo que llevan adelante profesores como Gonzalo Vicci y Fernando Miranda, quienes van perfilando un rico entramado de propuestas sugerentes que nos llegan desde este pequeño pero fascinante país de Sudamérica. En esta ocasión se trata de dos volúmenes recopilatorios que responden a dos acciones concretas: por un lado el trabajo que se viene realizando para descentralizar las tareas universitarias y llevarlas a zonas alejadas de la capital, como es el caso de Paysandú, y por otra parte los resultados de un coloquio impulsado por la Unidad de Formación y Apoyo Docente del Instituto de Artes. Sigo este mismo orden para secuenciar mi texto.

El primero de los títulos, el recopilatorio coordinado por Vicci, parte de un concepto de trabajo que ha dado buenos resultados. Cuando se le encargó al IENBA que realizase actividades en el Centro Universitario de Paysandú, sus responsables consideraron oportuno trabajar en el formato de seminario-taller de corta duración, 
con temáticas específicas que son abordadas de manera acotada en el tiempo. De este modo se utiliza una herramienta flexible que permite incorporar a diferentes actores sociales y educativos del medio local en actividades que se realizan en el espacio universitario. Las buenas prácticas de estas acciones ha dado como resultado la posibilidad de pensar, discutir y reflexionar acerca de las condiciones de producción y circulación de las artes visuales en el momento actual. Con esta positiva actitud, en Paysandú pudieron llevarse a cabo seminarios impartidos por Irene Tourinho, Raimundo Martins, Martín Vergés, Reyes González y Enéritz López. Han sido sus miradas diversas las que han dado forma a un conjunto heterogéneo y tremendamente válido por la contundencia de las distintas colaboraciones.

El enfoque crítico que plantea Enéritz López cuestiona las narrativas asociadas a una manera de ver e interpretar la historia del arte y el campo artístico en general. Por su lado Raimundo Martins insiste en la construcción de narrativas individuales que acaban impregnando nuestro entorno a través de las miradas y las visualidades que delimitan lo social. Para Irene Tourinho una de las claves es la presencia de la heteronormatividad como un engranaje a superar incentivando los feminismos, y lo hace desde el análisis de las viñetas de la revista científica Pesquisa. También Reyes González plantea la experiencia de cada docente como forma de definir el espacio desde donde pensarse, dando paso a la reflexión personal, biográfica e íntima. La lectura de cada uno de los ensayos recopilados sirve para que (como nos recuerda E. López) poner en marcha nuevas formas de enseñar y aprender en horizontalidad, en colaboración, partiendo de los sujetos y teniendo en cuenta sus circunstancias. Así pues, unas miradas nómadas que posibilitan, desde Paysandú, una serie de reflexiones oportunas y válidas para cualquier otro territorio geográfico.

Arianna Fasanello recoge en el volumen compilatorio que nos presenta una serie de intervenciones que pretenden debatir numerosas cuestiones desde un enfoque crítico. En el libro se analizan temas relacionados con las prácticas educativas y la cultura visual, sus espacios de investigación y sus posibles conexiones. Si bien el título del volumen resulta un tanto amplio, ya que es poco concreto, lo cierto es que en el tratamiento de cada uno de los textos comprobamos que predomina la transversalidad, de manera que se cubren aspectos tan diversos como la accesibilidad, las identidades, los productos y procesos artísticos, las representaciones, las construcciones y los discursos. A mi entender, entre las partes más llamativas del volumen destacanaquellas en las que se abordan las prácticas de creación y aprendizajes colaborativos, entendiendo estas prácticas como formas de intercambio y creación de significado a partir del encuentro con otros, así como los estudios desde el cuerpo como sujeto y espacio de acción. La compiladora destaca las aportaciones bibliográficas por parte de los diferentes autores, lo cual pone de relieve el papel que ha tomado la cultura visual y los estudios culturales en la nueva propuesta que llega desde la educación en artes y la investigación en este tipo de materias. 
Considero muy estimulante que se anime a estudiantes, docentes de diversa procedencia, y a investigadores que preparan sus tesis doctorales, a que planteen en un foro abierto sus dudas, sus intereses, sus fortalezas y su deseo de avanzar en el terreno de las geografías de la educación artística. De este modo podemos escuchar la voz de May Puchet cuando nos relata su mirada hacia el arte que se hizo en Uruguay durante la dictadura, basándose en los grupos de artistas. También se nos ofrece la posibilidad de conocer cómo ve Ilargi Olaizla educación artística tal y como se está evidenciando en la etapa de secundaria en España. O bien plantearnos la invisibilidad de las pedagogías queer a partir de las reflexiones que hace el profesor Belidson Dias, teniendo en cuenta las representaciones del género y la sexualidad en la cultura visual, centrándose esta vez en las manifestaciones estéticas y políticas de los besos, e investigando la relación que se crea entre el texto y el espectador como modelo interpretativo para una subjetividad crítica y activa en la educación artística.Dias incita a los educadores en arte a debatir cuestiones y representaciones de género y sexualidad en la cultura visual para la construcción de nuevas experiencias curriculares en educación artística.

Repiten aquí como autores, en relación con el volumen anteriormente reseñado, Irene Tourinho y Raimundo Martins. Por su parte, Fernando Miranda reflexiona sobre el concepto de cultura visual, en tanto que concierne a aquello que nos sirve para trabajar con las imágenes de todo tipo, instalándose en la idea de las visualidades en relación con las múltiples miradas posibles de los distintos sujetos, teniendo en cuenta que los educadores necesitan evitar las características estáticas de lo educativo y las recetas metodológicas. Le preocupa a Miranda analizar qué tipo de prácticas deberíamos promover para transformar lo pedagógico, atendiendo a algo tan identitario como que en cada caso abordado, las relaciones con la cultura visual son siempre situacionales. Así las cosas, y siempre valorando los esfuerzos de nuestros compañeros por articular un discurso más abierto hacia nuevas nociones, damos la bienvenida a estos libros que demuestran, una vez más, que los encuentros y desencuentros entre profesionales de la educación artística manejan una situación favorable a la globalidad y a escenarios propicios.

Ricard Huerta. Universitat de València 